\title{
Pamole' Beo': Pesta syukur padi petani ladang Dayak Tamambaloh di Kalimantan Barat
}

\author{
Efriania ${ }^{\mathrm{a}, 1^{*}}$, Haunan Fachry Rohilie ${ }^{\mathrm{b}, 2}$, Nahot Tua Parlindungan Sihaloho $\mathrm{o}^{\mathrm{c}, 3}$, Dea Varanidad ${ }^{\mathrm{d}}$ \\ abcd Universitas Tanjungpura, Jl. Prof. Dr. H. Hadari Nawawi, Pontianak, 78124, Indonesia \\ ${ }^{1}$ efriani@fisip.untan.ac.id ; ${ }^{2}$ fachryrohilie@fisip.untan.ac.id ; ${ }^{3}$ nahotsihaloho@fisip.untan.ac.id; \\ ${ }^{4}$ dea.varanida@fisip.untan.ac.id \\ Corresponding Author
}

\begin{tabular}{l}
\hline INFO ARTIKEL \\
\hline Sejarah Artikel: \\
Diterima: 29 Agustus 2021 \\
Direvisi: 3 September 2021 \\
Disetujui: 13 September 2021 \\
Tersedia Daring: 31 Oktober \\
2021 \\
\hline
\end{tabular}

Kata Kunci:

Berladang

Dayak Tamambaloh

Pamole' beo'

Upacara Syukur

Warisan Budaya Takbenda

\begin{abstract}
ABSTRAK
Penelitian ini dilatarbelakangi oleh fenomena diinkulturasikannya upacara syukur panen padi (Pamole' Beo') masyarakat Dayak Tamambaloh dengan perayaan Pentakosta Gereja Katolik, serta telah dijadikan ajang festival budaya. Fenomena ini tentu menunjukkan terdapatnya nilai-nilai luhur pada upacara Pamole' Beo'. Oleh karena itu, penelitian ini bertujuan untuk mengekplorasi nilai-nilai warisan budaya takbenda pada upacara Pamole' Beo' Dayak Tamambaloh. Penelitian dilakukan dengan pengamatan secara langsung dan wawancara mendalam dengan pendekatan etnografis. Penelitian ini, menunjukkan bahwa upacara Pamole' Beo' merupakan bagian dari ritus kehidupan berladang Dayak Tamambaloh. Ritus berladang ini dimulai dan diakhir dengan upacara Pamole' Beo' sebagai bentuk memanggil beo' atau pertanda-pertanda yang baik dan mengembalikan atau membuang beo' yang buruk. Berladang dan upacara Pamole' Beo' pada etnis Dayak Tamambaloh memiliki nilai-nilai yang luhur, yakni memperkuat ikatan sosial, menjaga kelestarian lingkungan alam, mentransmisi sistem pengetahun tradisional, mentransmisikan nilainilai karakter, nilai-nilai filosofi serta menjaga ketahanan pangan keluarga. Pemerintah Indonesia melalui instansi terkait, sangat penting untuk melakukan pencatatan dan penetapan Pamole' Beo' sebagai warisan budaya takbenda pada Etnis Dayak Tamambaloh, terutama karena sifatnya yang dinamis, retan untuk punah.
\end{abstract}

Keywords:

Dayak Tamambaloh

Farming

Intangible Cultural Heritage

Pamole' beo'

Thanksgiving Ceremony

\section{ABSTRACT}

The background of this study is the phenomenon that the rice harvest thanksgiving ceremony (Pamole' Beo') in Dayak Tamambaloh has been inculturated with the Pentecostal celebration of the Catholic Church, and has become a cultural festival. This phenomenon has certainly shown the existence of noble values at the Pamole' Beo' ceremony. Therefore, this study aims to explore the values of intangible cultural heritage at the Pamole' Beo' Dayak Tamambaloh ceremony. The research has been carried out by direct observation and in-depth interviews with an ethographic approach. This study, has shown that the Pamole' Beo' ceremony is part of the rite of life in the Dayak Tamambaloh farm. This farming rite begins and ends with the Pamole' Beo' ceremony as a form of calling Beo' or good omens, and returning or removing bad omens. Farming and the Pamole' Beo'ceremony in the Tamambaloh Dayak ethnic have noble values, namely strengthening social bonds, preserving the natural environment, transmitting traditional knowledge systems, transmitting character values, philosophical values and maintaining family food security. The Indonesian government, through the relevant agencies, is very important to record and stipulate the Pamole 'Beo' as an intangible cultural heritage of the Tamambaloh Dayak Ethnic, mainly due to its dynamic nature, prone to extinction. 
How to Cite: Efriani, E., Rohilie, H. F., Sihaloho, N. T. P. \& Varanida, D. (2021). Pamole' Beo': Pesta syukur padi petani lading Dayak Tamambaloh di Kalimantan Barat. Satwika : Kajian Ilmu Budaya dan Perubahan Sosial, 5(2), 229-240, https://doi.org/10.22219/satwika.v5i2.17938

\section{Pendahuluan}

Pamole' Beo' merupakan fenomena kebudayaan masyarakat petani padi ladang pada etnis Dayak Tamambaloh Kabupaten Kapuas Hulu, Kalimantan Barat. Pamole' Beo' dimaksudkan sebagai suatu upacara syukur dan juga permohonan berkat bagi benih padi yang akan ditanam pada tahun berladang berikutnya. Bagi Dayak Tamambaloh, Pamole' Beo' merupakan tradisi leluhur yang sarat dengan nilai-nilai luhur yang terinternaslisasi dalam kehidupan mereka. Oleh karena itu, upacara Pamole' Beo' merupakan perayaan yang meriah. Perayaan dilaksanakan secara rutin setiap tahun.

Pada Dayak Tamambaloh di Kabupaten Kapuas Hulu, Pamole' Beo' sebagai upacara syukur panen padi telah dilaksanakan secara turun temurun. Ada beberapa fenomena yang menarik pada budaya Pamole' Beo' pada suku Dayak Tamambaloh ini. Pertama, sejak masuknya agama Katolik pada pada 1978 yakni 65 tahun setelah Gereja Katolik masuk dalam kehidupan Dayak Tamambaloh, untuk pertama kalinya diadakan inkulturasi Pamole' Beo' dalam Misa Pentakosta (Efriani, 2021). Inkulturasi ini disebut dengan Pamole' Beo' Sarani. Hingga saat ini inkulturasi budaya Pamole' Beo' Tamambaloh diakulturasikan dengan Pesta Pentakosta Gereja katolik yang dilaksanakan 50 hari setelah hari Raya Paskah. Fenomena kedua ialah telah diselenggarakan kegiatan Pamole' Beo' Tamambaloh dalam bentuk festival, layaknya pekan gawai dayak yang dilaksanakan pada tingkat provinsi.

Diinkulturasikanya Pamole' Beo' ke dalam perayaan Gereja Katolik karena terdapat nilai-nilai luhur dalam tradisi Pamole' Beo' Dayak Tamambaloh yang selaras dengan ajaran Gereja Katolik. Dipamerkan Pamole' Beo' sebagai suatu pariwisata budaya, dan tentunya juga karena nilai-nilai tradisi yang menarik untuk dipertunjukkan. Dua hal ini, menjadi faktor pendorong bagi penulis untuk mengungkapkan kepada pembaca tentang budaya Pamole' Beo' Dayak Tamamabloh serta nilai-nilai yang terkandung di dalamnya sebagai warisan budaya tak benda.

Fenomena budaya seperti Pamole' Beo' memang bukan hanya terdapat pada etnis Dayak Tamambaloh. Padi dan berbagai hasil panen dari kehidupan pertanian, telah membawa petani di Indonesia pada berbagai upacara-upacara khusus yang berhubungan dengan hasil pertanian, misalnya, budaya gawai padi pada suku Dayak yang tersebar di pulau Kalimantan bahkan hingga ke Sarawak Malaysia (Elyta, 2021). Di pulau Sumatera terdapat kerja tahun suatu pesta syukur hasil panen padi tradisi masyarakat Karo. Tradisi yang berhubungan dengan pertanian padi begitu penting sehingga dilakukan acara khusus sebagai upacara syukur maupun kegembiraan atas hasil yang diperoleh. Di Pulau Jawa, seperti pada suku Sunda, terdapat tradisi seleh taun mapag taun, yaitu upacara untuk merayakan panen sekaligus menyambut tahun baru (Sejati, 2015). Tradisi mappadendang pada masyarakat Bugis yang memiliki makna sebagai ungkapan rasa syukur kepada Tuhan atas berhasilnya panen padi di suatu daerah (Puspitasari \& Fatimah, 2016). Kenduri Sko atau pesta panen pada masyarakat Kerinci di Jambi yang memiliki pengaruh sosial dan ekonomi terhadap kehidupan masyarakat (Ramadani \& Qommaneeci, 2018). Di Pulau Timur Indonesia, juga ditemukan pesta syukur, diantaranya ritual penti yang merupakan pesta upacara sebagai wujud 
syukur atas hasil panen yang berlimpah berupa kopi, vanili, cengkeh, dan juga padi pada masyarakat Kampung Puntu di Manggarai Timur (Agus, Arjani, \& Darmana, 2018), dan budaya Pa'ol Sera suatu upacara syukuran panen dalam tradisi Orang Kewar di Belu (Ande, Gabriel, \& Mali, 2014).

Pada suku Dayak, pesta syukur atas hasil panen padi, kini menjadi fenomena yang sangat menyita perhatian berbagai lapisan masyarakat. Pesta syukur atas panen padi ini dikenal dengan istilah umum dengan sebutan gawai padi. Gawai padi sudah dilaksanakan secara turun temurun oleh suku Dayak, sebagai bagian dari ritual yang erat kaitannya dengan penghargaan terhadap padi (Yogi, 2018). Di Kalimantan Barat khususnya, terdapat pekan khusus pada bulan Juni, untuk perayaan gawai padi yang disebut dengan Pekan Gawai Dayak (PGD) (Djafar, 2019). Pekan Gawai Dayak di Kalimantan Barat hingga tahun 2021 telah diselengarakan yang ke-35 kalinya (Sutiana, 2021), karena sempat tertunda pada tahun 2020 sebagai dampak dari pandemi Covid19. Pekan Gawai Dayak diselenggarakan besar-besaran dengan berbagai kegiatan di dalamnya.

Pekan Gawai Dayak Provinsi Kalimantan Barat telah menjadi fenomena yang marak juga diselenggarakan hampir setiap kabupaten bahkan tingkat kecamatan. Pekan Gawai Dayak meleburkan setiap suku Dayak, yang tidak sedikit banyaknya. Setiap suku tanpa memilah dirinya sebagai subsuku Dayak tertentu bersama menyukseskan kegiatan Pekan Gawai Dayak. Padahal, setiap suku Dayak, masing-masing memiliki tradisi khusus dalam melaksanakan pesta syukur padi, misalnya Suku Dayak Kayan Medalam merayakanya dengan pesta dange (Praptanya, Efriani, \& Dewantara, 2020), Dayak Meratus Halong merayakannya dengan pesta aruh baharin sebuah pesta panen padi (Pratama \& Nurcahyo, 2019), dan Dayak Kananyant mengenalnya dengan naik dango (Wina \& Habsari, 2017).

Beberapa kajian yang telah dilakukan tentang fenomena budaya pada masyarakat pertanian dan hasil panen, di antaranya berfokus pada pengkajian prosesi ritual fungsi dan makna ritual (Agus et al., 2018; Purba \& Febrianto, 2020; Puspitasari \& Fatimah, 2016; Sulistiyono, 2015), proses pelaksanaan dan nilai, terutama nilai-nilai religi yang terkadung di dalamnya (Ande et al., 2014; Pratama \& Nurcahyo, 2019). Sementara itu, kajian tetang Pamole' Beo' Dayak Tamambaloh ini dimaksudkan untuk mengungkapkan nilai-nilai warisan budaya tak benda (intangible cultural heritage) pada pesta syukur panen padi Dayak Tamambaloh.

Warisan budaya tak benda atau intangible cultural heritage merupakan warisan budaya yang bersifat tidak nyata, namun memiliki nilai yang luhur dan sebagai pembentuk karakter bangsa (Purba, Putra, \& Ardianto, 2020). Warisan budaya takbenda ini menjadi identitas bagi pemiliknya (Arizpe, 2004; Su, 2018) yang meliputi adat istiadat dan kebiasaan seperti tradisi dan ekspresi lisan, seni pertunjukan, praktik sosial, dan pengetahuan dan praktik tentang alam dan alam semesta (Van Zanten, 2004). Mengingat pentingnya warisan tak benda maka diperlukan upaya pencatatan dan kajian ilmiah terkait nilai-nilai luhur warisan budaya tersebut (Bonn, Kendall, \& McDonough, 2016).

Dengan demikian, kajian ini bertujuan untuk menggali dan menghimpun informasi tentang upacara Pamole' Beo pada Dayak Tamambaloh. Kajian ini dimaksudkan untuk menambah literatur terkait dengan studi budaya dalam kaitannya dengan kehidupan masyarakat petani di Indonesia. Kajian ini juga berkontribusi menambah khasanah kajian warisan budaya takbenda yang terdapat pada etnis-etnis di Nusantara.

\section{Metode}

Penelitian ini merupakan penelitian etnografis (Chawla, 2017) tentang pesta syukur seusai panen pada etnis Dayak Tamambaloh, di Kabupaten Kapuas Hulu, Kalimantan Barat. Penelitian ini berlangsung selama 3 bulan, yakni pada bulan April hingga Juni tahun 2019. Selama 
3 bulan, peneliti mengumpulkan data tetang kehidupan berladang etnis Dayak Tamambaloh. Pengamatan secara langsung serta wawancara secara mendalam (Denzin \& Lincoln, 1994), dilakukan dengan menggunakan bahasa Dayak Tamambaloh secara langsung. Tetua adat, dan pemimpin ritual Pamole' Beo' yang menjadi informan kunci dalam penelitian, menyampaikan informasi dalam bahasa Dayak Tamambaloh.

Penelitian ini menggunakan alat bantu berupa tape recorder guna mendokumentasikan hasil wawancara dan juga kata-kata atau doa yang disampaikan dalam upacara Pamole' Beo'. Selanjutnya, seluruh data dianalisis secara interaktif (Miles \& Huberman, 1994) dengan melakukan analisis domain, mengelompokkannya berdasarkan komponen-komponen yakni kehidupan berladang, konsep tentang Beo' atau tanda dan upacara Pamole' Beo'. Data atau informasi tersebut selanjutnya menyajikan ke dalam teks naratif dan deskriptif yang dilengkapi dengan istilah asli atau kata dalam Bahasa Dayak Tamambaloh (Fetterman, 2010).

\section{Hasil dan Pembahasan}

\subsection{Pertanian Ladang Dayak Tamambaloh}

Bercocok tanam dengan sistem berladang merupakan mata pencaharian utama Dayak Tamambaloh. Berladang menempatkan Dayak Tamambaloh sebagai komunitas yang hortikultural. Mereka adalah petani subsisten dengan tanaman utamanya adalah padi. Penanaman padi dilakukan pada lahan kering atau di ladang guna memenuhi kebutuhan konsumsi keluarga dalam jangka waktu satu tahun. Di ladang yang sama, bersama padi, mereka menanam tanaman-tanaman lain sebagai pangan penyangga kebutuhan rumah tangga. Tanaman-tanaman lain tersebut ialah sayuran dan beberapa jenis bumbu masakan dan juga obat-obatan.

Berladang merupakan pekerjaan yang cukup berat karena memerlukan waktu yang panjang serta dibutuhkan ketekunan. Oleh karena itu, sistem berladang umumnya dikerjakan bersama-sama dalam satu kelompok atau satu kampung. Bentuk kerja sama ini disebut dengan sipatulisan atau situlis. Situlis ialah bentuk kerjasama yang dihitung berdasarkan jumlah hari kerja dan jumlah orang. Misalnya, bila si A ikut dengan si B bekerja sama di ladang si B pada hari ini, maka besok si B akan membalas si A untuk bekerja sama di ladang si A. Kerja sama ini dikenal dengan sistem balas-balas hari dengan hitungan per orang, jika satu dibalas satu, dan jika dua dibalas dua. Dalam kerja sama ini dikenal beberapa istilah, yakni atulis ialah mengambil hari atau bekerja sama di ladang orang lain. Mamaar yakni membalas hari orang yang telah atulis. Baran yakni berhutang hari terhadap orang yang telah atulis. Misalnya baran saso, artinya berhutang satu hari, baran dua, berarti berhutang dua hari dan seterusnya. Mawa Baar ialah mengajak orang yang sudah ditulisi atau orang yang telah berhutang untuk bekerja sama di ladang sendiri. Suang Baar ialah orang-orang yang ikut bekerja sama di ladang orang yang Mawa Baar. Suang Baar mencakup orang yang mengambil hari atau atulis dan juga orang yang membalas hari atau mamaar.

Pertanian yang dilakukan Dayak Tamambaloh ialah pertanian dalam jangka waktu satu tahun dengan melalui berberapa tahap. Proses bertani atau berladang dimulai dari manyapa ' $i$, yakni satu hari yang khusus, dipilih dan didasarkan pada tanda-tanda alam (beo'), dan mimpi serta astronomis, umumnya dilakukan pada bulan Mei hingga Juni. Manyapa'i ialah langkah pertama, dengan tujuan meminta izin, memohon kepada penunggu tanah, hantu juga arwaharwah. Manyapa' $i$ hanya dilakukan dengan membersikan sebagian kecil lahan, umumnya kira-kira $3 \times 3$ meter persegi lahan yang hendak diladangi. Setelah manyapa' $i$, ladang tidak boleh didatangi selama 3 hari. Pada hari yang keempat, orang yang manyapa' $i$ datang kembali ke ladang dan mulai membersihkan lahan. Tahap ini disebut manjulung panyapa'an. Setelah manjulung panyapa'an, proses berladang 
dimulai dengan membuka semak belukar yang dikenal dengan masa atau tahap aruma, umumnya dilakukan selama 1 hingga 2 bulan yakni pada bulan Juni hingga Juli. Setelah masa aruma selesai yang ditandai dengan selesainya menebas atau membersihkan seluruh lahan yang hendak diladangi, maka dilanjutkan dengan masa manabang. Manabang ialah masa memotong atau menebang kayu-kayu yang ada di ladang. Setelah kayu-kayu seluruhnya sudah tumbang, ladang didiamkan selama kurang lebih 3-4 minggu hingga kayu-kayu dan semak-semak yang telah ditebas menjadi kering dan siap untuk dibakar yang biasanya dilakukan pada bulan Agustus. Setelah ladang dibakar, tahap selanjutnya ialah marapak. Marapak merupakan kegiatan membersihkan ladang dari sisa-sisa kayu yang tidak terbakar. Setelah masa marapak selesai dan ladang sudah bersih, tahap selanjutnya ialah menanam yang dimulai pada bulan September. Masa tanam dimulai dengan masa yang disebut masak. Masak ialah masa menugal, memasukan benih padi ke dalam lobang tugal. Masa ini dilanjutkan dengan tahap menyiangi yang dikenal dengan meet yang dilakukan pada bulan Oktober hingga November. Meyiangi ialah masa merumput, membersihkan padi dari rumput dan gulma-gulma yang dapat menghambat pertumbuhan padi. Setelah 4-5 bulan dari masa tanam, padi siap untuk dipanen. Masa panen dalam masyarakat Tamambaloh dikenal dengan sebutan matam yang dilakukan pada akhir bulan Desember hingga ahir bulan Januari. Seusai masa panen, diadakanlah upacara tahunan yakni upacara syukur sehabis panen yang disebut Pamole' Beo'.

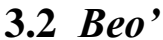

Seluruh proses berladang Dayak Tamambaloh dilakukan dengan melihat tanda-tanda alam seperti bulan, bunyi burung-burung dan binatang pemantang yang berfungsi memberi tanda atau petunjuk, hal ini disebut beo'. Jika tandatanda alam atau beo' ini tidak diperhatikan dan tidak dihiraukan, maka bencana kegagalan panen akan menimpa keluarga atau warga kampung. Dayak Tamambaloh sangat peka dalam 'membaca' beo'. Bila terdapat bunyi burung atau binatang yang dianggap sebagai pertanda buruk, maka mereka menafsirkannya sebagai pantang atau larangan. Konsep pantang melanggar beo' inilah yang menjadi esensi dari upacara syukur yang dilakukan sehabis panen, sebagai bagian penutup serta pembuka dari sistem berladang.

Beo' merupakan pertanda berupa simbol-simbol alam yang digunakan sebagai petunjuk bagi aktivitas harian Dayak Tamambaloh. Dayak Tamambaloh mengenal simbol-simbol tersebut sebagai pertanda. Penggunaan dan pemaknaan simbol-simbol, didasarkan pada peristiwaperistiwa yang dialami dalam kehidupan yang umumnya diperoleh dari alam sekitar. Pertanda tersebut berupa gejala-gejala alam misalnya petunjuk dari hewan seperti burung, ular, kijang juga pertanda dari tumbuhan misalnya pohon tumbang atau pohon jatuh. Selain itu pertanda juga diperoleh melalui mimpi.

Dayak Tamambaloh mengenal pertanda alam sebagai beo' jau' dan beo' maam. Beo' Jau' merupakan pertanda buruk. Pertanda ini jika dilanggar maka manusia akan mendapat kecelakaan, seperti luka, jatuh, sakit bahkan kematian serta ketidakberhasilan dalam pekerjaan yang sedang dilakukannya. Apabila beo' jau' terjadi pada saat bekerja atau hendak berpergian, orang yang mendengar atau melihat pertanda tersebut harus menghentikan aktivitasnya. Beo' maam merupakan pertanda baik. Pertanda ini memberi isyarat bahwa hal-hal yang sedang dikerjakan akan berhasil, manusia akan sehat dan selamat.

Beberapa benda-benda alam yang dijadikan pertanda atau beo' oleh Dayak Tamambaloh memiliki makna secara khusus. Antis adalah salah satu jenis burung yang suaranya digunakan sebagai pertanda atau beo' oleh Dayak Tamambaloh. Antis sabata' yakni antis dengan suara satu kata atau satu kali saja yakni Tik, dimaknai 
sebagai beo' jau', larangan untuk bekerja atau berpergian karena dalam pekerjaan atau perjalanan akan terjadi bahaya dan kecelakaan. Antis sakakar ialah suara antis dengan bunyi yang sering dan dalam waktu yang lama. Antis dengan suara ini dimaknai sebagai peringatan keras agar tidak melanjutkan pekerjaan atau berpergian. Suara antis sakakar merupakan beo' jau' atau pertanda buruk. Selai antis, juga terdapat pertanda buruk lainya atau beo jau' yakni burung Kutuk, Burung Buraga, burung Lambukan, sedangkan Burung Andak merupakan jenis burung yang suaranya digunakan sebagai pertanda baik atau beo' maam.

Ular merupakan salah satu reptil yang digunakan sebagai beo' (pertanda) oleh Dayak Tamambaloh. Ular dimaknai berdasarkan arah ular melintasi manusia. Ular yang melintasi dengan cara memotong perjalanan disebut urar mamolo yang dimaknai sebagai beo' jau' atau pertanda buruk. Jika ular yang searah dimaknai sebagai pertanda baik atau beo' mam. Selain hewan, beo' juga diberikan oleh pohon, diantaranya punggu' ialah suara pohon tumbang atau dahan kayu patah dan jatuh dimaknai sebagai pertanda buruk atau beo' jau' yang berarti kecelakaan bahkan kematian. Mimpi juga digunakan sebagai pertanda bagi Dayak Tamambaloh. Mimpi dapat berupa mui jau yakni mimpi buruk dan mui maam yakni mimpi yang baik.

\subsection{Pamole' Beo'}

Pamole' Beo' merupakan acara adat yang dilakukan pada akhir tahun pertanian untuk mengawali tahun pertanian berikutnya. Umumnya Pamole' beo dilakukan pada awal bulan Juni, namun penetapan jadwal pelaksanaan Pamole' Beo' kebanyakkan disesuaikan dengan kebutuhan dan kesepakatan masing-masing kampung. Pamole' Beo' diadakan oleh tiap-tiap kampung selama 1 hari 1 malam dengan masa pantang 3 hari 3 malam.

Pomole' beo' pada Dayak Tamambaloh ini, umumnya merupakan peristiwa yang sama dengan komunitas Dayak lainnya, misalnya Naik Dango atau ada juga yang menyebutnya Gawai Padi. Penyebutan Pamole' Beo' dalam bahasa Tamambaloh berasal dari dua kata yakni pamole' dan beo'. Pamole' yang berarti mengembalikan atau memanggil kembali dan beo' yang berarti pertanda berupa tanda-tanda alam yang digunakan sebagai petunjuk dalam keseharian Dayak Tamambaloh. Pamole $B e o$ ' dapat diartikan memulangkan tandatanda atau pertanda yang buruk dan memanggil tanda pertanda yang baik.

Berikut ini syair memanggil beo' yang baik dan memulangkan beo' yang buruk yang telah penulis rekam pada saat observasi secara langsung pada upacara Pamole' Beo, di dusun Nanga Liuk, 25 Mei 2019.

Molekin beo mamen' beo' baidiken, indi baras panggataku pangalongku, tajala ibona bua angkangin, tajala bonan awinanin. Beo' anu mamen, beo' paidikkangen, iyawa akokeen, iyawa aparuken. Beo burung andak, burung antisen, buragaan, babauen, takampit kausanai, angkankin. Ikin beo' paidikangen, beo mamen, takampit kausani angkankin, indi daun sakalanin, kalamenin, pulutin, suling baramin, takampitkin dudukin saro-aro sadapadap. Ikin beo ajauen takaloakin, indi baras panyiraku lo’in.

\section{Terjemahan bebas}

Kembalilah pertanda-pertanda yang baik, pertanda sumber rezeki, sumber kesehatan dan keselamatan. Dan kalian pertanda-pertanda yang buruk, menjauhlah dari kami. Datang pulalah hantu matahari, matahari yang memberi cuaca yang baik, memberi terang bagi kegiatan pertanian kami. Datanglah rohroh padi barok, padi kuntai, padi baute, padi manjin, padi bale', padi rabi', padi lembang, padi tutung adong, padi pebe, makan dan minumlah di sini berhadaphadapan. Kalian pertanda buruk, menghindarlah, ini beras untuk pengusirmu. (sumber: observasi penulis, 20 Mei 2019). 
Pamole' Beo' merupakan peristiwa yang sangat penting bagi Dayak Tamambaloh. Karenanya, pada masa menjelang Pamole' Beo' orang-orang menyiapkan diri serta perlengkapan yang dibutuhkan dalam acara. Pamole' Beo' menjadi ajang silahturami antarwarga kampung. Pamole' Beo' dirayakan dengan makan dan minum, terutama makanan dan minuman tradisional. Makanan dan minuman tradisonal tersebut berupa sumanan pulut (beras ketan yang dimasak dengan cara dibakar di dalam bambu), Sumanan kalame (campuran beras biasa dan beras ketan yang ditumbuk menjadi tepung, dimasak dengan cara dibakar di dalam bambu), Kalame Kuar (kue khas Tamambaloh, terbuat dari campuran beras ketan dan beras biasa yang ditumbuk, dimasak dengan cara dioseng selama 3-4 jam). Minuman tradisional yakni Baram merupakan air beralkohol hasil fermentasi beras dan beras ketan dimasak menjadi nasi dan difermentasi dengan ragi tape. Seluruh makanan dan minuman tradisional ini merupakan hasil pertanian pada tahun yang bersangkutan (gambar 1).

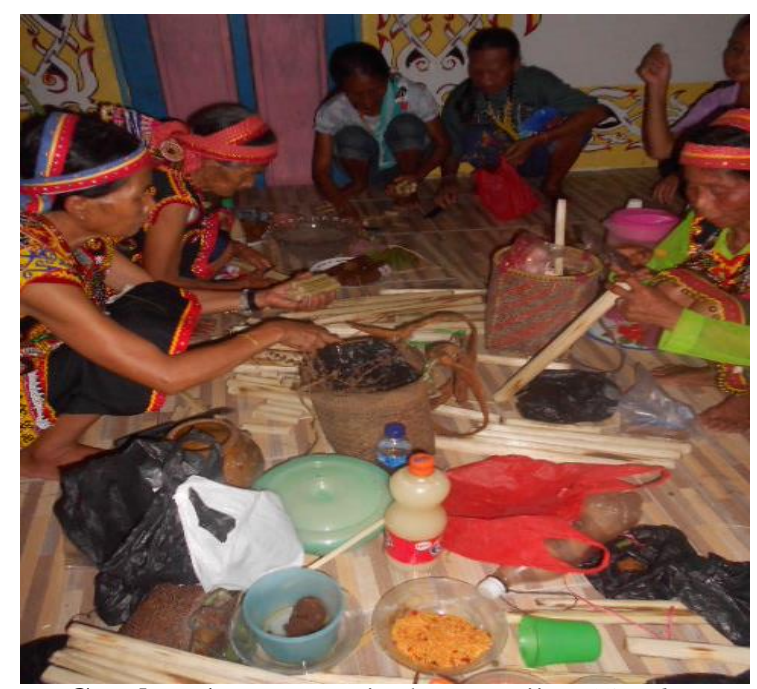

Gambar 1. Mempersiapkan sesajian (Sumber: Observasi, Kampung Karangkang 29 Mei 2019)

Acara inti dan terpenting dari Pamole' Beo' adalah Pamindara Banyia' yakni suatu ritual mengundang roh-roh leluhur dan roh-roh alam terutama roh-roh yang baik untuk hadir dan makan seperti tampak pada gambar 1 .
Berikut ini syair mengundang roh-roh leluhur dan roh-roh alam yang telah penulis rekam pada saat observasi secara langsung pada upacara Pamole' Beo, di Dusun Nanga Liuk, 25 Mei 2019.

Kutujuangkin loa antu Tamatoaan, antu tau joloen, antu pakule aseen, antu panabus, antunam orang Tamaoen. Kukalongkin kugatakin iak, tajala ibona bua angkangin baras pangalongku lo'in. Mangalongang pamindara banyi ka', banyia' to' iyawa aparuk ikam, iyawa karaja. Tujuang di tana' bainyaken, tana' balo'en, tana' datujuangen kolea alatala loam mantuari tioen. Ikin antuna ira baki ku-ira piangku, antuman orang tamaoen, naanki kukira naanki kudile'.

\section{Terjemahan Bebas}

Kutujukan pada roh-roh leluhur, roh-roh nenek moyang, roh-roh sumber padi, roh sumber rezeki, roh-roh leluhur orang Tamambaloh. Kupanggil, ini beras pamanggilku, jatuh tepat dihadapan kalian, tepat di atas pangkuan kalian. Ini aku memanggil kalian karena kami sedang Pamindara benih padi, benih padi yang akan ditanam di ladang. Mohon anugerahi kami tanah yang subur, tanah sumber padi. Roh-roh leluhur orang Tamambaloh datanglah, berkumpul di sini tanpa kupili-pilih. (sumber: observasi penulis, 20 Mei 2019).

Dayak Tamambaloh menyediakan makanan berupa sesajian dengan ritual manalayong. Manalayong yakni memberi makan roh-roh atau dalam bahasa Tamambaloh disebut maumpan antu tamatoa atau maumpan antu tau jolo. Gambar 2 menunjukkan makanan dan minuman yang dijadikan sesajian diletakkan di suatu wadah yang disebut Talayong, yakni wadah sesajian sebagai tempat berkumpulnya roh-roh para leluhur untuk makan dan minum. Terdapat dua bentuk talayong yakni talayong besar dan talayong kecil. Talayong kecil terbuat dari bilah-bilah bambu sejumlah 16 bilah yang dianyam berbentuk cekung atau pun persegi, 
sedang talayong besar disebut kalangkang. Kalangkang ialah talayong terbuat dari papan yang diukir berukuran $1 \mathrm{~m}-1,5 \mathrm{~m}$ (gambar 2).

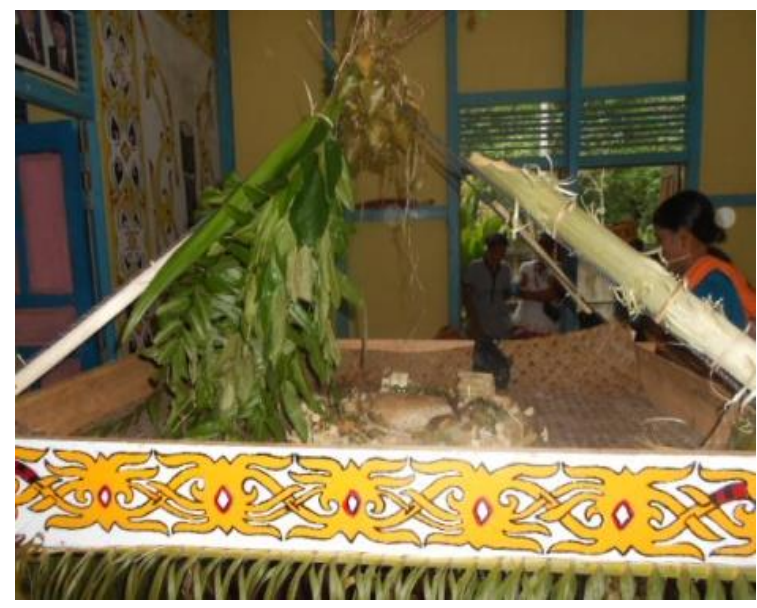

Gambar 2. Talayong/Sesajian (Sumber: Observasi, Kampung Karangkang 29 Mei 2019)

Adapun sesajian yang diletakan pada talayong berupa makanan dan tumbuhan. Makanan terdiri dari daun sakala, yakni satu canting beras yang dinanak menggunakan kuali, diletakkan di atas tikar dalam Kalangkang; 2 batang Pulut yakni beras ketan yang dimasak dengan cara dimasukkan dalam bambu dan dibakar hingga matang; 8 buah Kolombo yakni ketupat persegi lima yang diisi dengan beras biasa; 8 potong pulut, pulut yang dipotong sekitar 4-5cm; 2 ekor ikan yang di asapkan; 8 gulung kalame kuar yakni kue khas Tamambaloh yang terbuat dari campuran beras ketan dan beras biasa yang ditumbuk, dimasak dengan dioseng selama 3-4 jam; 8 sirap telur ayam kampung; 8 buah ilum yakni daun sirih yang diberi kapur dan daun gambir; 8 sirap buah pinang; 8 linting rokok tembakao kretek; 8 Tamayuk suling Baram; 2 lumpang baraam (Minuman khas Dayak Tamambaloh yang dihasilkan melalui fermentasi beras ketan dan beras biasa yang dimasak menjadi nasi, ditaburi ragi tape).

Talayong juga dilengkapi dengan dedaunan tumbuhan, yakni 8 lembar daun bararan sasait (daun akar bajakah); 8 buah bararan kakas (daun Pakis); 8 buah daun unto'-unto'; Takin bunga, dan 1 Lumpang ririas (bambu yang dihias).
Setelah semua bahan sesajian disajikan dengan lengkap, kemudian dilanjutkan dengan mangalongang. Mangalongang dalam ritual pamindara berarti memanggil roh-roh leluhur dan roh-roh alam yang bersifat baik. Mangalongang juga dapat berarti mengucapkan doa-doa yang dipimpin oleh satu orang yang telah ditetapkan dan bertanggung jawab karena garis keturunan, juga bertindak sebagai pemimpin ritual pamindara. Pamindara banyia" merupakan ritual memberi makan roh-roh leluhur, terutama roh-roh yang diyakini sebagai sumber rezeki, pemberi padi. Pamindara Bayia' juga bertujuan untuk meminta agar roh-roh leluhur, penguasa semesta, sampulo padari (Tuhan Dayak Tamambaloh) memberikan beo' maam (pertanda-pertanda yang baik), kesehatan dan keselamatan bagi segenap anggota keluarga dalam melaksanakan usah dan kerja sepanjang tahun yang akan datang.

Setelah dilakukan ritual pamidara banyia', seluruh penduduk kampung memasuki masa pantang atau tabu yang berlangsung selama 3 hari 3 malam. Adapun hal yang menjadi pantangan ialah tidak boleh berisik atau gaduh karena kegaduhan diyakini dapat mengganggu roh-roh nenek moyang yang sedang makan sesajian di talayong. Pantang ke luar perkampungan atau berjalan jauh dari perkampungan karena dapat menimbulkan bahaya keselamatan. Pantang membawa tumbuh-tumbuhan hijau atau tumbuh-tumbuhan segar ke dalam rumah karena diyakini dapat menimbulkan atau berefek pada kematian yang tiba-tiba (mate mata'). Setelah tiga hari berlalu, berakhirlah masa berpantang atau tabu, berakhir pula upacara Pamole 'Beo' dan kini mereka mulai mempersiapkan diri untuk beladang kembali.

\subsection{Nilai Warisan Budaya Tak Benda pada Pamole Beo}

Keberagaman etnik tradisional (Martono, et al., 2021) telah membawa Indonesia masuk dalam lima besar negara di dunia yang memiliki beragam warisan budaya (Ayu, 2017). Berbagai upaya telah 
dilakukan oleh pemerintah Indonesia serta para aktivis pemerhati budaya dalam upaya pelestarian budaya dan nilai-nilainya. UNESCO mendorong seluruh negara untuk melakukan pelestarian dan pemajuan warisan budaya tak benda di seluruh dunia. Di Indonesia pelestarian nilai budaya telah menjadi amanat Undang-Undang Dasar. Hingga tahun 2020 terdapat 1.239 warisan budaya tak benda yang ditetapkan oleh Kementerian Pendidikan dan Kebudayaan Republik Indonesia (Pusat Data dan Teknologi Informasi Sekretariat Jenderal Kementerian Pendidikan dan Kebudayaan, 2021).

Penetapan warisan budaya tak benda diberikan bagi warisan leluhur yang terus menerus dilakukan serta menjadi identitas bagi pemiliknya. Nilai-nilai yang luhur, tak lekang oleh zaman, bahkan memampukannya untuk bertahan dan beradaptasi.

Upacara Pamole' Beo' pada Dayak Tamambaloh memiliki nilai-nilainya yang sangat fungsional sebagai karya sosial, religius, filosofis, bahkan intelektual, menjadi warisan budaya tak benda terus dihidupi oleh pemiliknya. Berikut ini uraian nilai-nilai luhur warisan budaya tak benda pada upacara Pamole' Beo'.

Pertama, memperkuat ikatan sosial. Upacara Pamole' Beo' memiliki nilai yang memperkuat ikatan sosial dan jaringan sosial. Hal ini dapat dijumpai dalam aktivitas perayaan yang dilakukan secara bersama. Setiap orang terlibat secara aktif dalam perayaan. Kegembiraan dan suka cita meliputi seluruh masyarakat. Upacara Pamole' Beo' memberikan rasa identitas dan memperkuat nilai-nilai komunitas dan menyatukan setiap orang. Makan bersama, menari bersama dan melaksanakan pantang dan tabu secara bersama-sama. Studi ini, melengkapi fenomea budaya Kumpo Kampo pada masyarakat Larantuka di Kabupaten Flores Timur yang mengandung nilai kohesivitas (Dollu, 2020).

$K e d u$, menjaga kelestarian lingkungan alam. Bagi Dayak Tamambaloh, kehidupan, kamatian, kebahagiaan, kedamaian merupakan rangkaian dari kehidupan dan interaksi mereka dengan semesta. Alam tidak dipandang sebagai benda yang pasif, namun sebagai suatu yang aktif serta komunikatif (Efriani, et al., 2020). Pamole' Beo' merupakan manifestasi dari rasa hormat terhadap lingkungan alam dan semesta, sebagai sumber kehidupan dan tempat untuk hidup. Nilai budaya menjaga kelestarian lingkungan alam pada upacara Pamole' Beo' merupakan fenomena yang sama dengan budaya Larung Saji pada masyarakat di Ponorogo yang memiliki nilai-nilai arif dalam menjaga ekosistem laut (Putra, 2017; Yuliamalia, 2019).

Ketiga, mentransmisi sistem pengetahun tradisional. Sistem pengetahuan tadisional Dayak Tamambaloh tentang pertanda baik dan buruk, ditransmisikan dalam kehidupan sehari-hari mereka terutama dalam kehidupan pertanian. Pamole' Beo' menjadi media transmisi pengetahuan tradisional dari generasi ke genarasi. Adapun sistem pengetahuan tradisional yang ditransmisikan ialah, konsep tetantang alam dan semesta atau kosmologi Dayak Tamambaloh, pengetahuan dan keterampilan mengolah makanan tradisional, terutama yang digunakan sebagai bahan sesajian dan hidangan makan bersama. Pengetahuan tradisional menuntun Dayak Tamambaloh dalam interaksinya dengan lingkungan alam dan lingkungan sosial.

Keempat, mentransmisikan nilai-nilai karakter. Pendidikan karakter sangat dibutuhkan dalam membangun peradaban suatu bangsa (Dewantara, et al., 2020). Nilainilai karakter yang terdapat dalam warisan budaya tak benda sangat perlu utuk dikaji dan dikembangkan guna membangun peradaban bangsa Indonesia. Pada upacara Pamole' Beo' terkadung nilai-nilai karakter, seperti kerja sama atau gotong royong, tata krama, sopan santun, serta nilai-nilai religius. Fenomena ini, selaras degan nilai-nilai sosial yang terdapat pada tradisi Aruh Baharin Dayak Meratus Halong yang memiliki nilai menjaga ritual nenek moyang, membentuk nilai kesopanan tata krama, dan menjunjung nilai adat (Pratama \& Nurcahyo, 2019). 
Kelima, nilai-nilai filosofi. Pamole' $B e o$ ' sarat dengan filosofi dan nilai religius yang tercermin dalam rasa hormat kepada "yang maha kuasa" dan penghormatan terhadap roh para leluhur yang diungkapkan dalam pesta syukur. Dalam filosofi Dayak Tamambaloh, tanah, air, dan seluruh isi semesata harus dihormati. Mereka diundang untuk maka dan minum, hadir dalam upacara Pamole' Beo'. Fenomena ini tampak pula dalam kehidupan tradisi Subak pada pada masyarakat Bali, yang merupakan manifestasi dari filosofi Tri Hita Karana pada agama Hindu (Dewi, Sarjana, \& Wibawa, 2020).

Keenam, menjaga ketahanan pangan keluarga. Kehidupan bertani pada Dayak Tamambaloh telah menjadikan etnis ini mandiri dalam memenuhi kebutuhan pangannya. Meskipun padi merupakan tanaman utama, namun di ladang yang sama mereka juga menanam berbagai jenis sayur seperti timun, labu, kacang-kacangan, bayam, sawi dan beberapa jenis buah dan umbi, seperti jagung, ubi jalar dan singkong atau ubi kayu. Selain itu, di ladang yang sama juga ditanam berbagai jenis bumbu dan obatobatan. Dengan bercocok tanam, para petani ladang ini mampu memenuhi kebutuhan hidup sehari-hari serta menunaikan surplus sosial dan ritualnya (Rope, 2013).

\section{Kesimpulan}

Kehidupan masyarakat Indonesia yang disebut masyarakat agraris itu, telah memberikan aneka kebudayaan yang sarat dengan nilai-nilai luhur. Berbagai bentuk upacara syukur atas panen, memberikan makna yang mendalam tetang jiwa manusia nusantara yang penuh dengan rasa hormat dan bakti terhadap leluhur. Upacara syukur panen ini juga mencerminkan sikap religiusitas, kesadaran akan kehidupan yang merupakan pemberian dan anugrah yang Maha Kuasa yang disembah dengan berbagai cara, satu diantaranya dengan upacara Pamole' Beo'.

Pamole' Beo' sebagai upacara penutup dan pembuka dalam ritus berladang etnis Dayak Tamambaloh, merupakan suatu peristiwa gembira yang penuh dengan nilai yang baik. Upacara Pamole' Beo' ini memiliki nilai-nilai sosial, religius dan filosofis. Oleh karena itu, sistem berladang pada etnis Dayak Tamambaloh merupakan "sekolah" bagi etnis ini, sebagai tempat untuk belajar tentang nilai dan norma-norma kehidupan.

Pamole' Beo' sebagai pesta syukur padi pada petani ladang Dayak Tamambaloh di Kalimantan Barat, bukanlah fomena tunggal, namun memiliki nilai-nilai budaya yang luhur, yang berkontribusi bagi peradaban bangsa. Namun sifatnya yang dinamis dan adaptif, Pamole' Beo' rentan untuk berubah bahkan punah atau hilang. Oleh karena itu, pencatatan dan penetapan Pamole' Beo' sebagai warisan budaya takbenda pada Etnis Dayak Tamambaloh, penting untuk dilakukan oleh pemerintah dan pihak yang terkait dalam pelestarian nilai budaya.

\section{Daftar Pustaka}

Agus, A. Y., Arjani, N. L., \& Darmana, I. K. (2018). Ritual Penti Pada Masyarakat Desa Ndehes, Kecamatan Wae Ri'i, Kabupaten Manggarai, Flores, Nusa Tenggara Timur. Jurnal Humanis, Fakultas Ilmu Budaya Unud, 22(1), 166-173. https://doi.org/10.24843/jh.2018.v22.i $01 . p 26$

Ande, A., Gabriel, N. S., \& Mali, M. (2014). Pa'ol Sera: Upacara Syukuran Panen Dalam Tradisi Orang Kewar Di Belu. Jurnal Sejarah, 10(1), 16-31.

Arizpe, L. (2004). Intangible cultural heritage, diversity and coherence. Museum International, 56(1-2), 130 136. https://doi.org/10.1111/j.13500775.2004.00467.x

Ayu, M. R. (2017). Sistem Perlindungan Sumber Daya Budaya Tak Benda Di Palembang, Sumatera Selatan, Indonesia. Mimbar Hukum, 29(2), 205. https://doi.org/10.22146/jmh.16671

Bonn, M., Kendall, L., \& McDonough, J. 
(2016). Preserving intangible heritage: Defining a research agenda. Proceedings of the Association for Information Science and Technology, 53(1), $1-5$. https://doi.org/10.1002/pra2.2016.145 05301009

Chawla, D. (2017). Ethnography / Ethnographic Methods. https://doi.org/10.1002/978111890173 1.iecrm0090

Denzin, N. K., \& Lincoln Y. S. (1994). Introduction Entering the Field of Qualitative Research. In N. K. D. \& Y. S. Lincoln (Ed.), Handbook of Qualitative Research. Thousand Oaks, California: SAGE Publications, Inc.

Dewantara, J. A., Efriani, S., \& Prasetiyo, W. H. (2020). Optimization of Character Education Through Community Participation Around The School Environment ( Case Study in Lab School Junior High School Bandung ). Jurnal Etika Demokrasi, 5(1), 53-66. https://doi.org/https://doi.org/10.26618 /jed.v5i1.3017

Dewi, N. W. A. K., Sarjana, I. P., \& Wibawa, I. P. S. (2020). Pelestaria Subak Sembung Melalui Pendekatan Hukum Tradisioal di Desa Penguyangan Kaje. Paper Knowledge . Toward a Media History of Documents, 1(2), 12-20. Retrieved from https://ejournal.unhi.ac.id/index.php/h kb/article/view/1083/699

Djafar, A. (2019). Pekan Gawai Dayak Jadi Agenda Tahunan di Pontianak. Gatra.Com. Retrieved from https://www.gatra.com/detail/news/41 7417/lifestyle/pekan-gawai-dayakjadi-agenda-tahunan-di-pontianak

Dollu, E. B. S. (2020). Modal Sosial Modal sosial:Studi tentang Kumpo Kampo sebagai Strategi Melestarikan Kohesivitas Pada Masyarakat
Larantuka di Kabupaten Flores Timur. Jurnal Warta Governare, 1(1), 59-72. Retrieved from https://doi.org/10.1016/B978-0-08102295-\%0A5.10865-0\%0D

Efriani. (2021). Religi Nenek Moyang Dayak Tamambaloh dan Perkembangannya. Buddayah: Jurnal Pendidikan Antropologi, 3(1), 1-11. Retrieved from https://jurnal.unimed.ac.id/2012/index. $\mathrm{php} / \mathrm{bdh}$

Efriani, E., Dewantara, J. A., Utami, D., \& Listyaningrum, I. (2020). Ekologi Tradisional Dayak Tamambaloh. Jurnal Ilmu Lingkungan, 18(3), 503514.

https://doi.org/10.14710/jil.18.3.503514

Elyta, E. (2021). Gawai Dayak Festival and the Increase of Foreign Tourist Visits. Jurnal Global \& Strategis, 15(1), 167 186.

https://doi.org/10.20473/jgs.15.1.2021. 167-186

Fetterman, D. M., (2010). Ethnography; step-by-step (Third Edit). America: SAGE.

Martono, D. J. A., Efriani, \& Prasetiyo, W. H. (2021). The national identity on the border: Indonesian language awareness and attitudes through multi ethnic community involvement. $J$ Community Psychol, 1-15. https://doi.org/https://doi.org/10.1002/ jcop. 22505

Miles, B. M., \& Huberman, A. M. (1994). An expanded sourcebook Qualitative data analysis (Second Edi). London: Sage Publications, Inc.

Praptanya, D. B., Efriani, \& Dewantara, J. A. (2020). Dange: Synchronization Of The Catholic Church With Dayak Culture Of Kayan Mendalam. Jurnal Masyarakat Dan Budaya, 22(2), 4554. 
https://doi.org/10.14203/jmb.v22i2.10 76

Pratama, R. B., \& Nurcahyo, A. (2019). Kajian Sosioreligi Nilai-Nilai Upacara Aruh Baharin Dalam Masyarakat Dayak Meratus Halong Kabupaten Balangan Sebagai Sumber Pembelajaran Nilai Berbasis Multikultural. Agastya: Jurnal Sejarah Dan Pembelajarannya, 9(1), 94. https://doi.org/10.25273/ajsp.v9i1.364 0

Purba, E. A. B., \& Febrianto, A. (2020). Pesta Kerja Tahun Masyarakat Karo di Desa Batu Karang Kecamatan Payung Kabupaten Karo. Culture \& Society: Journal of Anthropological Research, 2(2), 88-97. https://doi.org/https://doi.org/10.24036 /csjar.v2i2.66 Pesta

Purba, E. J., Putra, A. K., \& Ardianto, B. (2020). Perlindungan Hukum Warisan Budaya Tak Beda Berdasarkan Convention for The Safeguarding Of The Intangible Cultural Heritage 2003 dan Penerapannya di Indonesia. Uti Possidetis: Journal of International Law, 1(1), 90-117. https://doi.org/doi.org/10.36565/up.v1i 1.8431

Pusat Data dan Teknologi Informasi Sekretariat Jenderal Kementerian Pendidikan dan Kebudayaan. (2021). Statistisk Kebudayaan 2021. Retrieved from

http://publikasi.data.kemdikbud.go.id/ uploadDir/isi_CC4179A6-B4FF4E0C-809B-5CADD9132AB5_.pdf

Puspitasari, R., \& Fatimah, J. M. (2016). Makna Pesan Simbolik Non Verbal Tradisi Mappadendang di Kabupaten Pinrang. Jurnal Komunikasi KAREBA, 5(2), 331-348. Retrieved from https://journal.unhas.ac.id/index.php/k areba/article/view/1911/1069

Putra, T. A. H. P. (2017). Kearifan Lokal Upacara Larungan Telaga Ngebel.
Jurnal Civic Hukum, 2(November), 65-77. Retrieved from http://ejournal.umm.ac.id/index.php/ju rnalcivichukum

Ramadani, Y., \& Qommaneeci, A. (2018). Pengaruh Pelaksanaan Kenduri Sko (Pesta Panen) Terhadap Perekonomian Dan Kepercayaan Masyarakat Masyarakat Kerinci, Provinsi Jambi. Jurnal Antropologi: Isu-Isu Sosial Budaya, 20(1), 71. https://doi.org/10.25077/jantro.v20.n1. p71-83.2018

Rope, R. (2013). Karakteristik sistem pertanian alami (Natural Farming) padi ladang di Kecamatan Morotai Timur. Agrikan: Jurnal Agribisnis Perikanan, 6(1), 37. https://doi.org/10.29239/j.agrikan.6.1. 37-51

Sejati, D. F. (2015). Seleh Taun Mapag Tau, Pesta panen ala sunda. Jakarta: Direktorat Kepercayaan Terhadap Tuhan YME dan Tradisi Direktorat Jenderal Kebudayaan Kementerian Pendidikan dan Kebudayaan.

$\mathrm{Su}$, J. (2018). Conceptualising the subjective authenticity of intangible cultural heritage. International Journal of Heritage Studies, 24(9), 919-937. https://doi.org/10.1080/13527258.201 8.1428662

Sulistiyono, I. (2015). Ken-Duren Wonosalam (Studi Deskriptif: Makna Ken-Duren Wonosalam pada Masyarakat Kecamatan Wonosalam, Kabupaten Jombang). Jurnal AntroUnairdotNet, 4(1), 77-85. Retrieved from http://journal.unair.ac.id/AUN@kenduren-wonosalam--(studi-deskriptif-makna-ken-duren-wonosalam-padamasyarakat-kecamatan-wonosalam,kabupaten-jombang)-article-8742media-134-category-8.html

Sutiana, W. (2021, June 2). Buka Pekan Gawai Dayak Ke XXXV, Wagub 
Kalbar Ajak Jaga Persatuan Dalam Perbedaan. Pemerintah Provinsi Kalimantan Barat. Retrieved from https://kalbarprov.go.id/berita/bukapekan-gawai-dayak-ke-xxxv-wagubkalbar-ajak-jaga-persatuan-dalamperbedaan.html

Van Zanten, W. (2004). Constructing new terminology for intangible cultural heritage. Museum International, 56(12), $36-44$. https://doi.org/10.1111/j.13500775.2004.00456.x

Wina, P., \& Habsari, N. T. (2017). Peran Perempuan Dayak Kanayantn dalam Tradisi Upacara Naik Dango (Studi di Desa Padang Pio Kecamatan Banyuke Hulu Kabupate Ladak Kalimantan Barat). JURNAL AGASTYA, 7(1), 104126. Retrieved from http://ejournal.unipma.ac.id/index.php/JA/arti cle/view/1063
Yogi, I. B. P. P. (2018). Padi Gunung Pada Masyarakat Dayak, Sebuah Budaya Bercocok Tanam Penutur Austronesia (Melalui Pendekatan Etnoarkeologi). Forum Arkeologi, 31(1), 45. https://doi.org/10.24832/fa.v31i1.456

Yuliamalia, L. (2019). Tradisi Larung Saji Sebagai Upaya Menjaga Ekosistem Di Wisata Telaga Ngebel Ponorogo (Studi Literatur). Agastya: Jurnal Sejarah Dan Pembelajarannya, 9(2), 135. https://doi.org/10.25273/ajsp.v9i2.387 8 